\title{
Transformation of Learning Management: Integrative Study of Islamic Boarding School Curriculum
}

\author{
Mukhamad Ilyasin \\ LAIN Samarinda, Indonesia \\ e-mail: sinka.ilyasin2010@gmail.com
}

\begin{abstract}
The existence of Islamic education e.g. Islamic boarding schools has contributed in the middle of social lives in Indonesia. Continuously, Islamic boarding schools have developed in accordance with social demand nowadays. Besides, Islamic boarding school education should make adaptation by doing many changes especially in the field of learning management through curriculum integration of Salafiyah and Kholafiyah in order to build Islamic boarding schools as a central for excellent. Therefore, as an effort to achieve intended goal, observation and interview were conducted to obtain the data regarding with description of learning management especially concerning with Salafiyah and Kholafiyah curriculums at Nabil Husein Islamic boarding school Samarinda. The findings indicate that the value of Islamic boarding school is assumed as a core value of curriculum development as shifting paradigm through Islamic boarding school learning management. That paradigm has correlation with institutional goals of Nabil Husein i.e. as Islamic education main controller with religious and moral values oriented. In addition, graduates of Nabil Husein are expected to master two types of knowledge fields i.e. general and Islamic knowledges with spiritual values, so that Islamic boarding school education graduates are able to integrate among social, emotion, and intelligence quotients. Further implication is also noticed and suggested in this research.
\end{abstract}

Keywords: Learning management transformation, Islamic boarding school education, integrative curriculum of Salafiyah and Kholafiyah

\section{A. Introduction}

Islamic boarding school education nowadays tend to focus on 4.0 industrial revolution which insist Islamic education plays its role dynamically and actively in the middle of globalization. Therefore, the existence of Islamic boarding school education depends on 
graduates' quality with social, emotion, and intelligence quotients. Sociologically, Islamic boarding schools in Indonesia rely on classical knowledge tradition or what so called by Salafiyah. Specifically, efforts on increasing quality of education system are done by implementing learning management transformation through curriculum integration i.e. Salafiyah and Kholafiyah in order to bring Islamic boarding school education to become the center of future Islamic civilization. The existence of Islamic boarding school education is vital whether its position as an educational institution (Al-Haiah Al Ta'lim wa Al-Tarbiyah), or as a public service institution (Al-Haiah Al Ta'awnni wa Al Takafuli, Al Ittijaahi). These roles are raised based on several aspects i.e. Islamic boarding school institutions are able to be a place of moral building which is integrated to Islamic knowledge. Whereas another important role of Islamic boarding school is society is as human and capital investment in increasing knowledge and skills of students (Fauzi, 2017).

Furthermore, many studies were conducted by previous researchers regarding with learning management transformation especially in the context of classical curriculum tradition i.e. Salafiyah and Kholafiyah at Islamic boarding schools. One of them is Basri (2011) who observed regarding with the dynamic of Islamic boarding school especially about educational friction of Salafiyah concept used at Gengong Islamic boarding school Indonesia. As the result, Basri (2011) found that Gengong Islamic boarding school still maintain to use Salafiyah curriculum in everyday activities of students e.g. the learning of Kitab Kuning, Kitab Fiqih, and memorizing the holy Qur'an. In fact, no specific friction existed but only try to adjust the learning process by the openness toward technological information, more comprehensive curriculum used which is relevant to present era. Alike with Basri (2011), Indra (2017) also investigated regarding with how Salafiyah curriculum system which is considered as traditional system used by Islamic boarding schools in Indonesia adjust in globalization era. Surprisingly, not only Basri (2011) and Indra (2017), an investigation toward how institution such as Islamic boarding schools accommodate surrounding social change following by technological improvement also done by Kusnadi, Sobur, \& Aziz (2017). As a result, they found that one of Islamic boarding schools exist in Jambi, in fact, is able to accustom to nowadays period e.g. by the existence of formal structure of the Islamic boarding school.

Unlike with Basri (2011), Indra (2017), and Kusnadi et al. (2017), Khojir (2014) observed how certain Salafiyah Islamic boarding in Samarinda contribute to instill multicultural aspects to students. Different research focus also studied by Nurwanto (2013), said that there is an eagerness among students of changing the traditional system in Islamic boarding schools i.e. rising the idea of modernization. In line with Nurwanto (2013), Anjarsari \& Susanto (2019) also investigated similar research focus i.e. modernization in Islamic boarding school education based on the thoughts of Prof. Dr. Muhaimin, M.A. Specifically, in Muhaimin's thoughts, modernization of Islamic boarding school can be done through the integration of multiculturalbased education.

Additionally, in terms of modernization, as general lesson such as English is taught in modern Islamic boarding schools, Al-Baekani \& Pahlevi (2018) observed teachers and students preferences of teaching and learning English subject, and as a result, they found that Community Language Learning was chosen both by teachers and students to be applied in teaching and learning process of English subject in classroom. Above studies indicate that there many researches focus that can be investigated in Islamic boarding schools, but none of them observed how Salafiyah and Kholafiyah education systems can be integrated and pertained. 
In this research, Nabil Husein Islamic boarding school became the research setting which consist of several levels of education i.e. primary, junior high, senior high, and vocational levels. Several considerations were taken to determine the research setting where based on the researcher's preliminary study done on November $16^{\text {th }}, 2019$, the researcher found that Nabil Husein Islamic boarding school becomes parental choice of education because it keeps on growing continuous quality improvement. As also reported by one of famous newspaper of Tribun Kaltim Samarinda, said that Nabil Husein Islamic boarding school is a great place for students to study both intellectual and religious wisdom and learning (Pratama, 2016). In this case, enthusiasm from parents increase every year and until the late of 2019, the total number of students from all educational levels exist at Nabil Husein, whether primary, junior high, senior high, and vocational high levels reach 300.000 students. Adequate facilities and the fact that graduates from Nabil Husein can integrate between religious knowledge and the general one become reasons why parents are enthusiastic on sending their children to study at Nabil Husein Islamic boarding school. It is assumed that learning management transformation through curriculum integration is well-implemented at Nabil Husein Islamic boarding school. In addition, the combination of Salafiyah and Kholafiyah in Islamic boarding school educational system has become a trend and the most successful one (Busyairi, 2017). Hence, based on above considerations, the researcher investigated the implementation of those two integrated curriculums at all level of education exist at Nabil Husein Islamic boarding school Samarinda.

\section{B. Literature Review}

\section{Learning Management Transformation of Islamic Boarding Schools}

At practical level, the transformation of learning management can run effectively and efficiently when every program at Islamic boarding school started through a managerial process including learning planning. It is because each learning program requires a plan, so that all activities can be directed to achieve institutional and learning goals at the same time. In addition, planning is essentially a basis for controlling various activities and achieving learning objectives (Rahmah, 2016). In this case, learning planning is a process carried out by the teacher in guiding, assisting, and directing students to have learning experiences for skills realization (Daryanto, 2013). Likewise, in a learning plan, several strategic steps are needed including analyzing environment of Islamic boarding schools, formulating operational goals, collecting various data or information, formulating and determining alternative programs, and establishing program implementation estimated as well as compiling program of implementation schedules (Usman et al., 2019).

Thus, improving the quality of Islamic boarding school education is significantly very dependent on the learning process and the implementation of learning depends on the transformation of management. Therefore, the effectiveness of learning depends on planning process including merits of planning where it should predict future activities e.g. if there is a failure regarding with learning objectives, it can be predicted that certain program activity is less and imperfect. Hence, considering policies, budgets, procedures, rules, methods, and criteria to achieve intended goals beforehand is very vital in a learning management transformation (Hassan, Wan, \& Widyarto, 2016).

The second important aspect of learning management before conducting learning activities, the role of Islamic boarding school education leaders must first establish various bases of educational organization through formulation of a vision and mission oriented for future 
based on the dynamics of current educational development. Therefore, it is expected that the leader of Islamic boarding school education as well as other leading staff can conduct preparation of learning programs in accordance with the needs of students and the community i.e. learning society and scientific society.

The third important aspect is related to students' management, where it is a process of regulating all forms of activities of students, from the very beginning until the end of learning process. Hence, the role of leadership in student management includes admission of a new students, coaching students at schools, and strengthening students' programs. In this case, the position of students in learning occupies a strategic position where the presence of students in learning activities in classrooms has brought a number of significantly different abilities one to another. This fact requires teachers' role to be able to manage learning activities through learning management. In this case, students' management in learning activities can be divided into several aspects i.e. task planning groups which means that a form of grouping based on the plan of task to be given by the teacher. The second students' management is teaching groups where this kind of group is used for group teaching. Meaning that the teacher instructs students to do same task at the same time. The third students' management is seating groups which means that forming groups in general e.g. students are seating around a table. Meanwhile, the fourth students' management is joining learning groups which means that grouping of students where one group of students works with activities interrelated with other groups. Finally, collaborative groups become the last students; management where a working group focuses on the cooperation of each individual and the results as efforts applied on finishing certain task (Bafadhal, 2014).

The next important aspect of students' management is related to enhancing teacher professionalism through various trainings in order to improve teachers' performance in teaching. In this case, performance of teachers is considered to be crucial to the effectiveness of management of learning and closely related to teachers' productivity (Hanim et al., 2019, Ebadi \& Gheisari, 2016; Ilyasin \& Zamroni, 2017; Fauzi, 2018). This theory is supported by National Education System (2003) No. 20 article 35 paragraph 1, stated that national education standards include facilities and infrastructure, management, funding and assessment of education, as well as teacher professionalism which should be maintained their sustainability in a planned and periodic manner. Therefore, teachers' duty is not easy where they should have several competencies including managing learning management, preparing learning process, implementing teaching and learning interactions in classrooms, assessing students' performances, as well as providing feedback toward the result of students' learning achievement. In addition, aspects of academic mastery are also highly vital i.e. teachers' understanding of educational insight as well as conquering learning materials being taught (National Education System, 2003).

Moreover, the fifth students' management aspect is concerning with the development of preparation in learning activities. In this case, the role of teachers is that they must pay attention to the students' interest and its connection to materials used. Therefore, teachers' job isn't only to transfer knowledge but also motivator to evoke students' learning enthusiasm and encourage students to learn by using a variety of media and learning resources which are suitable for students. Hence, teachers should highlight several principles in order to develop learning activities i.e. clarity of competency formulation and teaching preparation, simplicity and flexibility of teaching preparation, connectedness between teaching preparation and activities 
applied toward the competencies being set, sustainability of components of school programs implementation especially when learning is carried out in teams or what so called by team teaching (Mulyasa, 2004).

The next students' management is regarding with students' quality learning. In this case, various efforts are needed by teachers as well as having high sensitivity whether learning activities run effectively or not. In order to anticipate certain failure, concrete steps must be applied by teachers i.e. plans to be implemented, being critical, creative and productive in producing learning aids, analyzing teaching materials, and preparing various assessment instruments (Karli, 2004).

Furthermore, learning evaluation, measurement, and assessment activities become the seventh aspect in students' management. Former expert of educational evaluation, Kourilsky (1972) explained that evaluation is an act of determining students' capability individually. In this case, the concept of learning evaluation is always developed until the present time. Lee et al. (2019) described that evaluation process is generally student-centered which is intended to observe student learning outcomes as well as an attempt to determine how to create learning opportunities. In addition, Lee et al. (2019) add that it is not merely about evaluating students' performance, evaluation is also intended to observe teachers' role, specific learning strategies, curriculum materials, and principles applied in teaching. The theory from Lee et al. (2019) indicate that students are usually become the center of evaluation, even though teachers are actually also become the important element to be assessed because they are directly involved and engaged with students in teaching and learning process. However, teaching and learning process is a complex activity that requires careful observation and analysis so that supervisor teams can easily develop teachers to have great capability to manage learning process (Bafadhal, 2014).

Moreover, evaluation becomes one of the tasks that should be carried out by teachers to determine how far the success of students is (Hanim et al., 2019). Learning evaluation activities are more directed to several aspects i.e. in the field of teaching which is used as a basis for decision making about what teachers should teach and what students have learned. The second aspect is learning outcomes, measurement and evaluation are not only used to determine the level of understanding and mastery, but also provide an overview of the achievement of the program in learning as a whole. The next important aspect of evaluation is diagnosis and improvement of learning where there is possibility of learning difficulties occurrence, therefore, teachers should figure out the causes and provide various alternative solutions toward students' learning problems. In addition, evaluation should result students' placement to differ their ability. Other than that, curriculum also should be noticed as it is as the relying foundation whether it is implemented by teachers in classroom learning. Finally, institutional assessment will significantly have positive influence in order to improve the quality of Islamic education in accordance with current development.

\section{Research Methodology}

In order to figure out the research focus concerning with holistic understanding about transformation of learning management through integrative curriculum of Salafiyah and Kholafiyah, qualitative approach and case study were applied in this research (Taylor, Bogdan, \& DeVault, 2016; Miles, 2014). Moreover, the learning management transformation was observed at all educational levels existed at Nabil Husein i.e. primary, junior high, senior high, and 
vocational levels. Natural phenomenon was described by the use of direct observation and in dept interview (Creswell, 2008; Miles, Huberman, \& Saldana, 2014). In addition, document study also done to support the data regarding with learning management transformation through Salafiyah and Kholafiyah curriculums applied by Nabil Husein Islamic boarding school Samarinda.

\section{Findings}

Concerning with the research focus that the researcher figured out, it is found that the transformation of learning management in Nabil Husein Islamic boarding school Samarinda aimed to improve the quality of Islamic education generally starting from primary, junior high, senior high, and vocational levels. Therefore, an effort on integrating educational curriculum i.e. Salafiyah and Kholafiyah are used to produce superior outcomes. Generally, it is found that Nabil Husein Islamic boarding school can integrate and develop the curriculum used by learning activities provided for students in classrooms and sort of media used during teaching and learning process.

In addition, teachers at every level can transform the goal of implementing the curriculum into classroom learning activities. In the curriculum used, it contains the formation of characters, knowledge, and skills. Particularly, it is reflected from the subjects to be learned by students. Students does not merely learn what so called by Kitab Kuning as it used by any Salafiyah Islamic boarding school in Indonesia as well as requiring students to memorize Al-Qur'an, but Nabil Husein also provide general knowledges which the students need in this technological era i.e. English, computer literacy, and other general lessons. Moreover, students are also provided to join many kinds of extracurricular activities e.g. martial arts, hadrah (one of famous Islamic arts). In addition, several routine events such as manasik haji and Idul Adha celebration programs are held and provided for students. Additionally, teachers are also given opportunities to be improved by joining certain kind of activities such as motivation training from famous motivator entrepreneur.

Particularly, interview to the top leaders of all educational levels at Nabil Husein Islamic boarding school indicates that the content of Salafiyah and Kholafiyah curriculum aimed to develop three aspects which mentioned above is based on several consideration i.e. to face future challenge Islamic education, to become an agent of change, as well as to realize that Islamic education is the pioneer of huge Islamic educational institutions. Other than that, the integration of Salafiyah and Kholafiyah curriculums set by Nabil Husein Islamic boarding school are included aspects of development and learning, student coaching strategies, and religious materials to improve the spiritual knowledge of students.

Moreover, to actualizing one of institutional goals of Nabil Husein Islamic boarding school i.e. to create balance performance among spiritual, emotional, and intelligence quotients, top leaders of every educational levels apply connection between physics, senses, spirituals, verbalistic (qauliyab), and empirical elements in lives (kauniyab). These findings, somehow, drive Nabil Husein Islamic boarding school reach success both in academic and non-academic fields. This fact is part of curriculum integration as well as transformation of learning management in each educational unit at Nabil Husein Islamic boarding school. In short, learning is carried out as an implementation of the curriculum used by using an integrated learning model through internalization of values in learning. 
Moreover, there is no difference between integrated Islamic boarding school components of Nabil Husein and other Islamic boarding schools which consist of inputs, supporting elements, the process of learning activities, and output or results. Those elements are constituted to the scope of development of integrated Islamic boarding school education. The progress of an education is determined by aspects of readiness, availability, and quality of its components. In addition, the basic conception of Nabil Husein Islamic boarding school is based on core value of curriculum development by involving all elements including school, parents, and school surrounding environment as part of integrated Islamic education. The integration gives positive influence to the graduates of Nabil Husein Islamic boarding school where they tend to equalize among social, emotional, and intelligence quotients as well as applying learning management based on institutional vision and mission.

Below figure indicates how all important elements are connected each other and end up with institutional goals:

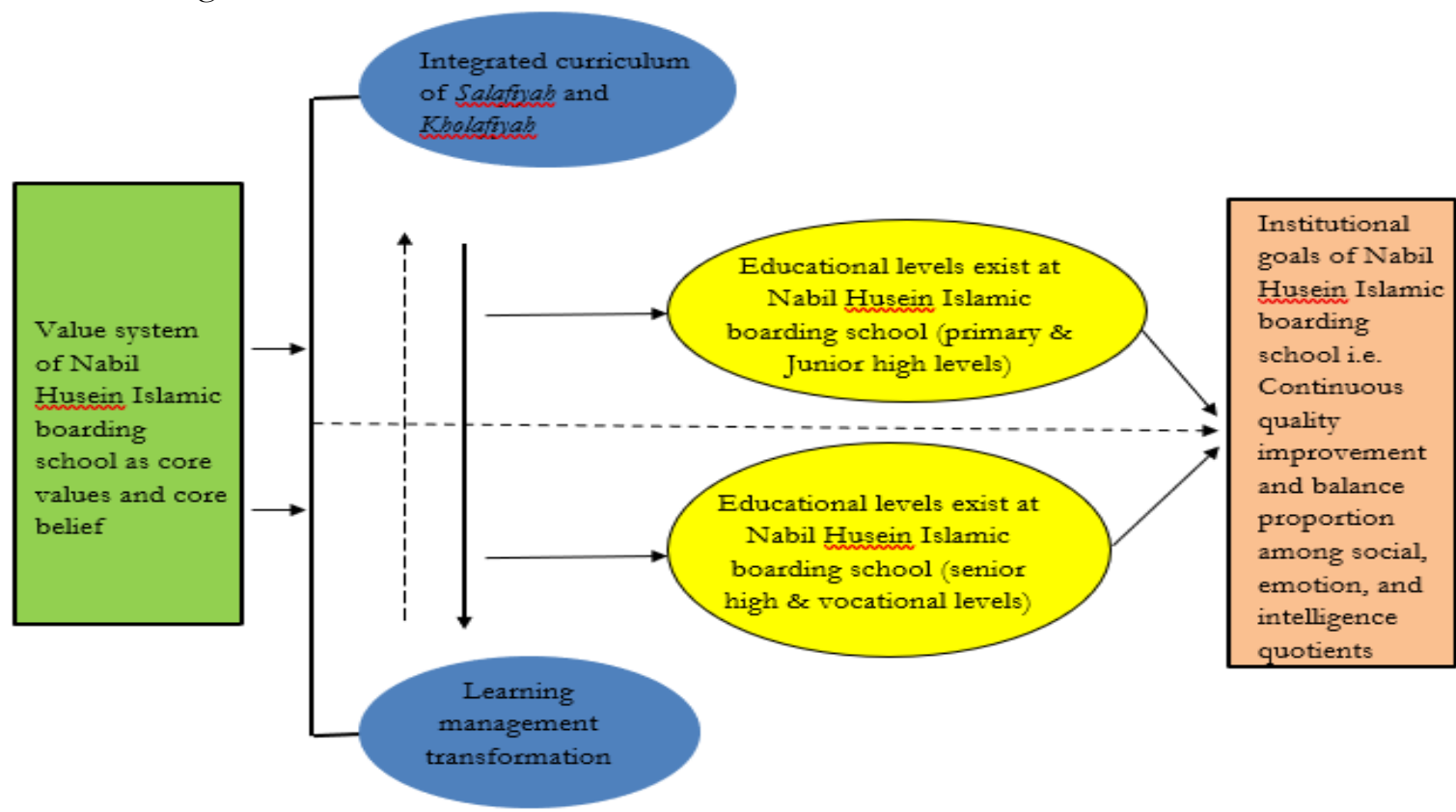

Above figure is the result from document analysis from all levels of education exist at Nabil Husein Islamic boarding school starting from primary, junior high, senior high, and vocational high school levels. Educational system at Nabil Husein is started from core values and core beliefs as the relying steps on learning management transformation including when integrating the curriculum used. Secondly, learning management transformation i.e. integrated curriculum of Salafiyah and Kholafiyah is applied at all levels of educational levels at Nabil Husein Islamic boarding school. Lastly, the integrative concept of Salafiyah and Kholafiyah in curriculum used by all educational levels should meet similar goals of institution i.e. continuous quality improvement as well as balance amount among social, emotion, and intelligence quotients.

\section{E. Discussion}

Based on the findings above, it showed that all educational level starting from primary until vocational levels can integrate between Salafiyah and Kholafiyah concepts on curriculum 
used. It was indicated by the ability of teachers to imply the content of those systems to the context of learning activities of students. This result proves that to integrate Salafiyab and Kholafiyah is a great choice since it is demanding and preferred to be used in Islamic boarding schools nowadays in order to balance general and religious knowledges of students. No wonder if the assimilation of both Salafiyah and Kholafiyah beliefs become the most trending one so that the graduates of Islamic boarding schools can compete to the 4.0 industrial industry at the present time (Busyairi, 2017). It also confirms the reported news exposed by Tibun Kaltim Samarinda with the news tagline "Nabil Husein, a combination of modern and traditional Islamic boarding school"(Pratama, 2016).

Surprisingly, the idea of modernization is actually not a new term as there are quite many of Islamic boarding schools in Indonesia start to apply essential meaning of modernization toward learning management (Setyawan, 2016). Previously for years ago, former scientist i.e. Mastuhu (1994) has proposed the concept of modernization in traditional system of education and following by curriculum reconstruction. Regardless of whether it is effectiveness of not, Mastuhu (1994) proposed modern learning activities in Salafiyah Islamic boarding schools in terms of learning activities are possible to be changed, for example, in traditional system e.g. bandongan, sorogan, and halaqah are common learning formats which tend to focus on teachercentered method, whereas in the modern one, teachers can actually switch the learning paradigm by applying student-centered method and provide students for discussion. In other words, the fact that Nabil Husein as an Islamic boarding school that can integrate and develop both general intellectual capability of students as well as religious aspects has been proven in the context of inside and outside of Nabil Husein Islamic boarding school.

Not only for students, Nabil Husein Islamic boarding school also pay attention to the needs of having qualified teachers by providing them additional activities instead of only teaching in classrooms such as participating to any kind of valuable workshop e.g. joining motivation training program and scientific learning models (PRO Samarinda, 2019a; 2019b). This result confirms the theory of essential elements in learning management transformation where aspect of professional teachers is a must to be highlighted by certain institution to have more valuable and qualified teachers (Hanim et al., 2019; Ebadi \& Gheisari, 2016). It is because there must be challenging factors when teaching in classrooms such as facing students with different capabilities or intelligences. In addition, there is highly possibility of students to have different background. Those two examples of challenging substances make the top management of certain Islamic boarding schools prepare their teachers to teach students with any condition. (Ilyasin \& Zamroni, 2017; Fauzi, 2018).

Furthermore, one of institutional goals of Nabil Husein Islamic boarding school i.e. to have balance students' performance of students in terms of social, intelligence, and emotion quotients is confirmed by the research done by Takviana (2017), said that the duty of Islamic boarding schools is not only in terms of teaching students to have religious knowledge, but they need more than that element in order to face the world which is rapidly changed. Therefore, future implication of this research suggested that Islamic boarding schools exist in Indonesia which still apply only Salafiyah as traditional system used to try to assimilate the Salafiyah with Kholafiyah systems of education, especially when arranging institutional curriculum. It is intended to balance among all three types of quotients i.e. social, intelligence, and emotion. 


\section{F. Conclusion}

From findings and discussion provided above, it is obvious that transformation of learning management is an important part especially in developing management of certain formal institution. Several points to be concluded are the integration of Salafiyah and Kholafiyah systems exist at Nabil Husein Islamic boarding school Samarinda is considered as appropriate choice to be applied. In addition, as there are many studies which focused on modernization applied in Salafiyah Islamic boarding schools, in this case, Nabil Husein Islamic boarding school also focuses on the integration of Salafiyah and Kholafiyah which indicated by the combination of formal learning activities provided for students inside classrooms as well as extracurricular activities outside the classrooms. Not only for students, Nabil Husein Islamic boarding school also afford teachers to have valuable programs out of teaching activities e.g. joining workshop of motivation training and experiencing on producing various learning models. In addition, the integration between Salafiyah and Kholafiyah educational systems in curriculum used by Nabil Husein reflected by the institutional goals set i.e. aimed at producing graduates who have balance proportion among social, intelligence, as well as emotion quotients.

\section{BIBLIOGRAPHY}

Al-Baekani, A. K., \& Pahlevi, M. R. (2018). Investigation of English Learning Model at Traditional Islamic Boarding School (Pondok Pesantren Salafiyah) Darul Ulum Al-Barokah Karawang. JUDIKA (JURNAL PENDIDIKAN UNSIKA), 6(2), 1-5.

Anjarsari, P., \& Susanto, H. (2019). Reconstruction of Islamic Education (Study of Islamic Education Thoughts of Prof. Dr. Muhaimin, M.A.). Jurnal Al-Ta'dib, 14(1), 53-64.

Bafadhal, I. (2014). Perencanaan Pengajaran Berdasarkan Pendekatan Sistem. Jakarta: PT. Bumi Aksara.

Basri, H. H. (2011). Pesantren Zainul Hasan Genggong: Dinamisasi Pendidikan Berbasis Salafiyah Kultural. Badan Litbang Dan Diklat Kementerian Agama RI, 9(1), 4232-4251.

Busyairi, M. (2017). No TitleEducation Unit Transformation for Maintain Its Existence in Islamic Boarding School (Multi-case Study on Tebuireng Islamic Boarding School, Gading Islamic Boarding School Malang, and Sidogiri Islamic Boarding School Pasuruan). Journal of Education and Practice, 8(5), 56-64.

Creswell, J. W. (2008). Educational Research. Planning, Conducting, and Evaluating Quantitative and Qualitative Research (3rd ed.). London: Pearson Prentice Hall.

Daryanto, D. (2013). Inovasi Pembelajaran Efektif. Bandung: Yrama Widya.

Ebadi, S., \& Gheisari, N. (2016). The Role of Consciousness-Raising through Critical Reflection in Teachers' Professional Development: A Sociocultural Perspective. Cogent Education, 3(1), $1-14$.

Fauzi, A. (2017). Persepsi Barakah di Pondok Pesantren Zainul Hasan Genggong; Perspekstif Interaksionalisme Simbolik. Al-Tahril, 17, 105-132.

Fauzi, A. (2018). Analysis Study of Parental Choice of Education in The Millenial Era. Nadwa: Jurnal Pendidikan Islam, 12(2), 311-330.

Hanim, Z., Masyni, M., Soe`oed, R., \& Asiah, S. N. (2019). Learning Innovation Management on Effective Classes at SMPIT Cordova Samarinda. DINAMIKA ILMU, 19(2), 225-236.

Hassan, W., Wan, B., \& Widyarto, S. (2016). A Formulation and Development Process of Information Security Policy in Higher Education. Proceeding the 1st International Conference on Engineering and Apllied Science (InCEAS) 2016, ISBN: 978-602-14930-8-3. Purwokerto: 
University of Muhammadiyah Purwokerto.

Ilyasin, M., \& Zamroni, Z. (2017). Balanced Scorecard: A Strategy for the Quality Improvement of Islamic Higher Education. DIN AMIKA ILMU, 17(2), 223-236.

Indra, H. (2017). Salafiyah Curriculum at Islamic BOarding School in the Globalization Era. TARBIY A: Journal of Education in Muslim Society, 4(1), 74-88.

Karli, H. (2004). Kurikulum Berbasis Kompetensi. Bandung: Bina Media Informasi.

Khojir, K. (2014). Penanaman Nilai-Nilai Multikultural (Studi Kasus Pada Pesantren Nabil Husein Samarinda Kalimantan Timur). DIN AMIKA ILMU, 14(1), 65-80.

Kourilsky, M. (1972). Learning Through Advocacy: An Experimental Evaluation of an Adversary Instructional Model. The Journal of Economic Education, 3(2), 86-93.

Kusnadi, E., Sobur, K., \& Aziz, A. (2017). An Islamic Boarding School: A Study of Al-mubarok Al-Islam Within the Social Changes of Seberang Kota Jambi. ADDIN, 11(1), 101-130.

Lee, S. M., Lee, D., \& Kim, Y. S. (2019). The Quality Management Ecosystem for Predictive Maintenance in the Industry 4 . 0 Era. International Journal of Quality Innovation, 5(4).

Mastuhu, M. (1994). Dinamika Sistem Pendidikan Pesantren. Jakarta: IPB Bogor and INIS.

Miles, M. B. (2014). Qualitative Data Analysis: A Methods Sourcebook (3th ed.). Arizona State University: Sage Publication, Inc.

Miles, M. B., Huberman, A. M., \& Saldana, J. (2014). Qualitative Data Analysis: A Methods Sourcebooks (3rd ed.). California: SAGE Publications, Inc.

Mulyasa, M. (2004). Kurikulum Berbasis Kompetensi 2004. Bandung: PT. Remaja Rosdakarya.

National Education System. (2003). National Education System Law. Jakarta: Ministry of National Education.

Nurwanto, N. (2013). "Desire for Change" among Students in Traditional and Modern Islamic Boarding Schools (Indonesia). The 6th International Indonesia Forum. Yogyakarta: State Islamic University of Sunan Kalijaga.

Pratama, A. (2016). Ponpes Nabil Husein, Perpaduan Pesantren Modern dan Tradisional. Tribun News.

PRO Samarinda. (2019a, August). Ponpes Nabil Husein Gelar Training Motivasi Datangkan Motivator Enterpreneur dari Jateng. Samarinda Pos.

PRO Samarinda. (2019b, October). Adakan Diseminasi Modul 1 KKM 1 dan Tanoto Foundation, MTs Nabil Husein Jadi Tuan Rumah. Samarinda Pos.

Rahmah, S. (2016). Mengenal Sekolah Unggulan. ITQAN, 7(1), 11-22.

Setyawan, C. E. (2016). Menggagas Model Pengembangan Standarisasi Sistem Pendidikan Pesantren. Jurnal Al-Ta'dib, 11(2), 227-240.

Takviana, M. (2017). Culture Internalization at SMP Islam Al-Azhar Tulungagung in Fostering the Students' Spiritual Quotient. Didaktika Religia, 5(1), 225-246.

Taylor, S. J., Bogdan, R., \& DeVault, M. L. (2016). Introduction to Qualitative Research Methods : a Guidebook and Resource (4th ed.). New Jersey: John Wiley \& Sons, Inc.

Usman, N., AR, M., Syahril, S., Irani, U., \& ZA, T. (2019). The Implementation of Learning Management at the Institution of Modern Dayah in Aceh Besar District. 1st International Conference on Advance and Scientific Innovation (ICASI). Banda Aceh: Politeknik Kutaraja, Banda Aceh. 